\title{
INTERCULTURAL MEDIATION THROUGH PICTUREBOOKS
}

\author{
Margarida Morgado
}

\begin{abstract}
Picturebooks are good resources for intercultural mediation with children given their multimodality and topic range related to contemporary living. When carefully selected, picturebooks may help children reflect on the multicultural world they live in and learn about meaningful intercultural action. Some examples of picturebooks are used from the Identity and Diversity in Picture Book Collections project (IDPBC) in order to explore topics related to the superdiversity of contemporary societies, such as, living in communities, multiple linguistic identities, approaches to mass migration and (voluntary and enforced) mobility. Fictional resources such as these are capable of generating empathy in readers and thus can be used to help children understand the growing cultural diversity around them, as well as the social phenomena of migration, refugees. These fictional resources may also contribute to children's understanding of social complexity at the global scale, at the human rights level, and within rules of democratic action as global citizens. Some inclusive didactic approaches are further suggested for using the selected picturebooks with five to 12-year old children in contexts of intercultural mediation.
\end{abstract}

\section{KEYWORDS}

Picturebook; identity; diversity; migration; intercultural mediation

\section{MEDIAÇÃo INTERCULTURAL COM ÁlBUNS ILUSTRADOS}

\begin{abstract}
Resumo
É grande o potencial de utilização de livros-álbum no contexto da mediação intercultural com crianças e jovens, que recorrem à multimodalidade para contar histórias sobre condições sociais de vida mundo atual. Quando criteriosamente selecionados, os livros-álbum permitem aos jovens encontrar representações diversas de multiculturalidade e de atuação intercultural significativas. Apresentam-se alguns exemplos de como um conjunto de livros-álbum da coleção do projeto IDPBC (Identity and Diversity in Picture Book Collections) pode ser usado para explorar tópicos de superdiversidade das sociedades modernas, tais como, viver em comunidades culturalmente muito diversas, construção de múltiplas identidades linguísticas, mobilidades humanas (forçadas e voluntárias) e migrações, em massa. Estes recursos ficcionais, que se apresentam como geradores de empatia entre os leitores, podem ser usados para ajudar crianças a compreender a diversidade crescente em que vivem, bem como os fenómenos contemporâneos de migração ou refugiados. Eles podem também contribuir para ajudar os jovens a compreender a complexidade social à escala global e ao nível dos direitos humanos e da convivência na diversidade de uma cidadania global. Sugerem-se por fim abordagens didáticas inclusivas destes materiais, passíveis de serem usadas com crianças (com idades dos cinco aos 12 anos) em situações de acolhimento e mediação intercultural.
\end{abstract}

\section{Palavras-chave}

Livro-álbum; identidade; diversidade; migração; mediação intercultural 


\section{INTRODUCTION}

Meek (1991) once wrote that we are the stories we tell in the sense that societies create fictions that people then live by in that society (Meek, 1991). She also acknowledged that the idea of fictions shaping people's lives might be uncomfortable for many people. However, any fictional or non-fictional narrative we share with others is in fact a strategy used to construe reality, rethink the past, present a version of ourselves and of our identities, or a means by which we look for similarities and for re-imagining ourselves, others and the world itself. To read a story or to tell a story are fundamental actions of meaning production, of naming that which is not yet named or of (re)constructing real events into something else. The choice of a story or of the way we tell it represents a worldview. Bruner (1986) claims, in fact, that narrative is a way of thinking, which we shape or remember as real, about people who become actors and have intentions and about whom we care (Djikic, Oatley \& Moldoveanu, 2013, p. 30).

However, caution is needed about the stories we tell. In a recent Ted Talk entitled The danger of a single story (Adichie, 2009), the USA-based Nigerian writer Chimamanda Ngozie Adichie speaks of the importance of reading and telling stories, in the plural, while signalling the dangers of the "single story" and of the reproduction of preconceived ideas, discrimination, prejudice, stereotypes and populism. At the heart of her talk against ethnic, racial and social discrimination she calls attention to how important stories are: those we tell each other, those that eventually get published, and those that are read inside and outside of school. These stories are strategies to represent societies, which eventually become dominant narratives, while simultaneously running the risk of reducing concrete lived experiences to clichés.

Since reading and listening to stories are a way to produce and re-produce culture, it is of the utmost importance to select narratives that are representative of contemporary societal issues if the aim is to use stories to learn about contemporary living. There are a couple of useful questions that may be used to select particular stories, such as how is a particular cultural aspect or event rendered in the story? Who tells it? How is it told? To what effect? Given that "we do not see what we do not know", how is it that stories (in the plural) can enrich our knowledge and recognition of represented reality?

Apart from carefully selecting stories on specific topics or themes for children, it is equally fundamental to consider which intercultural mediation strategies might be effective to engage children in thinking about complex social phenomena and to do so without any need to significantly reduce their complexity. Furthermore, consideration is due to mediation strategies that will develop the skills and competences children will need in order to live with growing cultural and linguistic heterogeneity at school and superdiversity in society (Vertovec, 2006). The ethnic, social and linguistic diversity across each migrant group that used to be defined in terms of its geographical location in a town or its social and economic status or ethnicity has now to be opened to a different notion. The concept of superdiversity throws light on all the variables that may intersect in any migrant's life trajectory and set him or her apart from the rest of 'his group' in contemporary societies. 
This chapter thus debates the potential benefits of using selected picturebook stories for intercultural mediation with children and young people. It sets picturebooks out as multimodal representations of reality that need to be carefully selected if they are to be used for the purpose of learning about contemporary societies. This is the time when diverse populations and cultures come into contact as they have never done before in time-space, not only more often but also in a larger scale, not only because of voluntary or enforced migration and mobility, but also due to the daily presence of the digital media of the Information Society. So, the chapter further highlights a particular social configuration that deserves attention, namely multilingualism in schools and in multicultural societies and the need for $21^{\text {st }}$ century education to explore issues of identity and otherness in action explicitly and intentionally.

The chapter then proceeds to consider how any careful selection of fictional resources has to be explored through socio-constructivist pedagogical approaches. Telling, sharing and listening to or reading stories is linked to the development of two competences: intercultural communicative competence and global citizenship.

The main argument for this chapter is that primary education requires new worldviews and that these can be shared and critically learned from contemporary picturebooks. This is only possible because picturebooks have recently become more involved with the representation of global diversity as well as local human action that resonates globally, and also because recent studies have shown how stories in picturebooks can help readers feel empathy for those they often see as 'others'. In this sense picturebooks can become extremely useful resources to educate children towards democratic global citizenship.

The second argument is that the multimodality of picturebooks renders them useful tools for the development of multiliteracies. Multiliteracy competences are crucial to understand what is happening in a world that uses complex forms of representation based on the spoken word, images and some writing, in striking contrast to school literacy, still predominantly linked to learning how to read and write. Thus, by focussing on picturebooks, where image and text live off each other, we also wish to promote emergent pedagogies that are socio-constructivist in nature, inclusive, learner-centred, interactive and experiential. Our proposal is to look at picturebooks as a means to mediate complex social problems in school environments that are increasingly growing more culturally diverse, essentially because children themselves start thinking through pictures and not through writing, but also because a picture related to a story does not constitute a linguistic barrier as an oral or written text do. Pictures are, in that sense, particularly suited to foster communication in multilingual spaces.

The chapter proceeds with a brief definition of the two competences, intercultural communicative competence and global citizenship, which this chapter describes as outcomes of engaging with telling or reading stories through picturebooks. These core competences described in most European primary curricula will be developed through analysis and inclusive exploration of picturebooks from the "IDPBC - Identity and Diversity in Picture Book Collections" project in the context of intercultural mediation actions to 
be developed in significantly diverse classrooms in terms of the home cultures and the home languages of the children in them. Three main objectives have been set for the selection and use of these picturebooks, namely: learning to live in culturally diverse communities, understand how children build multiple linguistic identities, and understand migration and mobility in contemporary societies.

\section{EDUCATING FOR GLOBAL CITIZENSHIP AND DEVELOPING INTERCULTURAL COMMUNICATIVE COMPETENCE}

Contrarily to what used to happen, all children will inevitably frequently engage today with heterogeneous cultural behaviour and events, both face-to-face when they contact other people and through what they see and read on digital media. In order to make sure that these contacts become encounters, rather than (cultural) shocks, children should learn to become critically and knowledgably aware of what surrounds them, and thus develop the skills, attitudes and knowledge deemed necessary to live a full life in (super)diverse places, to communicate efficiently in culturally and linguistically diverse spaces (that is, develop intercultural communicative competence) and further learn how to become global citizens.

\section{GLOBAL CITIZENSHiP}

Global citizenship is a frequently contested term, given the wide scope of its use and the ambiguity it implies. Oxley and Morris (2013, p. 301) call attention to how easy it has become to use this concept to refer to situations as diverse as the ban on the veil worn by Muslim women in western societies; promote diversity work grounded on religious difference; deconstruction of hegemonic points of view in Western societies; or empowering citizens with the competences to resolve conflicts and counter social injustice.

Although it integrates primary school curricula, the development of citizenship education is not often addressed as a "global" issue and is often linked to education for development, for human rights and for peace (Oxley \& Morris, 2013, p. 302).

By attempting to anchor intercultural mediation through picturebooks in the concept of global citizenship, in this chapter we make use of the notion by Parekh (2013, p. 12) of a globally oriented citizen, one that is geographically based on a specific territory, although aware and attentive to local repercussions in the global. We also include in global citizenship the competences that are generally defined, normatively, in educational contexts, for building citizenship in times of considerable cultural and linguistic diversity, such as, become aware of oneself in the world; become aware of human responsibility on the planet; learn about other cultures; develop empathy and responsibility for others at the global scale.

\section{INTERCULTURAL COMMUNICATIVE COMPETENCE}

The educational competences just referred are often used to promote a kind of intercultural education, which requires from children that they not only learn to know 
themselves in order to adequately respond to others in intercultural encounters, but also become aware of how they are becoming multiple identities, that are flexible and in flow (Sen, 2006).

As an example, let us consider the curricular orientations for primary Science, year 4, in Portugal (Ministério da Educação, n.d., pp. 100-114), which expects children to "develop respect for other peoples and cultures and reject any type of discrimination" (Ministério da Educação, n.d., pp. 103-104). There are also references to discovering others through their customs and traditions, when these realities are part of school. While, for year three, there is mention to learning about the cultures of minorities that might eventually live in the neighbourhood or community, with a focus on customs, language, food and music (Ministério da Educação, n.d., p. 108).

However, in our view, the intercultural communicative competence that will equip children to successfully communicate in a globalized world definitively goes beyond learning about other peoples and cultures, to encompass the savoirs defined by Byram (1997). It is important to learn how to be / become, how to critically engage with others and how to learn in order to not only discover about other people, but also interact with them (Byram, 1997). Byram's (1997) intercultural communicative competence model may be summed up as the manifest ability of learners to work with and collaborate effectively with learners from other cultures. This requires knowing how to engage the appropriate communicative behaviour and how to negotiate diverse identities in a culturally diverse environment. Intercultural communicative competence includes intercultural awareness, intercultural sensitivity and intercultural effectiveness.

One of the intercultural effectiveness measurement scales available, by Portalla and Chen (2010; see also Mendenhall, Stevens, Bird, Oddou \& Osland, 2011), a validated instrument used to measure an individual's capacity to attain communicative objectives in intercultural interactions, assesses interest and curiosity for people of other cultures, as well as interest in being well understood (which they call the continuous learning dimension, further subdivided in self-awareness and exploration). It further assesses interest in understanding other peoples and in maintaining relationships with people that are different from us (which is defined as the interpersonal engagement dimension, subdivided into global mind set and relationship interest). Finally, it also assesses how individual are able to understand the psychological and emotional differences that may concur to establish points of contact, thus diminishing the psychological effort required from interacting with people that are different (called the dimension of Hardiness, further divided into positive regard and emotional resilience).

Adapting the dimensions of intercultural effectiveness and the development of intercultural communicative competence into concrete classroom activities requires, in our view, that learning activities explicitly involve diverse perspectives on the same topic, thus enhancing exchanges of opinions from diverse points of view. Furthermore, materials and resources have to yield diverse perspectives on the same topic. Thirdly, working groups should include members from diverse origins or from diverse contexts in classroom dynamics that open up space for all present to share their points of view (Gregersen-Hermans, 2015, p. 47). 
As regards the use of fiction to develop this competence, a study published in 2013 by a team of researchers from the University of Toronto, Djikic et al. (2013) concludes that participants (among college students) who initially did not reveal openness to others, after reading short fictional texts, and in opposition to those who read non-fiction essays only, showed higher open-mindedness after reading fiction.

The authors conclude that although reading non-fiction may be useful to learn about any subject, it does not help thinking about it. A fictional text will, in true essence, be about the social world, about individuals who interact in the social world and thus raises the cognitive empathy of readers, namely their capacity for social reasoning and their emotional interest. In this research study empathy was measured in terms of the ability of the individual to adopt the point of view of others (cognitive empathy); and of compassion for the less fortunate (emotional empathy).

Although it may not be possible to make direct links from the results of this study to children's engagement with narratives in picturebooks, or even assume that feelings of emotional empathy towards others as a result of reading will be sustained over time, these results nonetheless open up new avenues of thought on how fiction may be used to learn to engage with others and to develop empathy. Results also point to the need to explore in more depth the area of children's fiction in education so as to promote attitudes of greater openness and empathy in children.

In terms of fictional engagement, these aspects relate to how readers are willing to identify with the narrative worldview, the objectives and intentions of fictional protagonists, how they feel aligned with certain characters, and how they become close to what is told as if they had taken part in it. Djikic et al. (2013, p. 33) additionally call attention to the functions of simulation that are triggered by fictional narratives, as they invite readers to imagine worlds that are within the limits of possibility and to guess probable disclosures. Moreover, fictions promote emotional involvement and understanding of the emotions of others (other characters) and their thoughts. Research by Speer, Reynolds \& Zacks (2009) corroborates that reading fictional simulations involve the exact same brain structures used for comparable actions and perceptions in real life, without the eventual negative impacts and incomprehension or cultural shock (Speer et al., 2009, p. 33).

Studies in this area with pre-school children correlate as positive the stories the children were told and the films they have watched and the development of empathy at this stage, in clear opposition to, for example, watching television (Speer et al., 2009, p. 34).

\section{IMAGINING THE GLOBAL WORLD AND HOE CHILDREN BUILD LINGUISTIC IDENTITIES}

Several primary curricular topics might be selected to develop global citizenship in primary schools, both from a normative and an experiential perspective, although primary resources seldom use those we will mention or approach them through picturebooks..

It makes sense to organise intercultural mediation activities, to be led by teachers or social educators, around broad topics and to define learning aims for those topics. As an example of how to engage with the IDPBC collection of picturebooks, a topic might 
be selected concerning local issues in connection to global issues, namely Imagining the global world and within this broad topic elect to discuss how linguistic identities are constituted in order to highlight that linguistic identities are constructed and that each individual may exhibit multiple linguistic identities.

This choice of topic for developing intercultural mediation through picturebooks determines the need to combine a set of picturebooks and didactic approaches capable of promoting awareness of the linguistic diversity in the global/ised world by involving all students and building on their cultural and linguistic diversity.

However, this is a sensitive topic that worries teachers and mediators in multicultural schools and that they have problems in addressing; their concern is often how to fully understand children and young people who come from different cultures, speak different languages and have been previously schooled in quite different contexts.

Connected to the issue of multilingualism at school is the social issue of mass migration that also needs to be addressed. Contemporary societies are the stage of growing voluntary and enforced mobility at the global scale. It is thought that every single individual will have to learn several languages throughout life in order to travel, learn, work and live in places which, even though some will continue to exhibit dominant single cultures, will become increasingly more international and multilingual. Moreover, critical access to digital information and multimedia, freedom of speech (to consume and produce content) and empowerment through a voice that can be heard in a global world (Unesco, n.d.) determine use of certain languages of power.

Furthermore, linguistic issues of effective communication are often marginalised from intercultural mediation. Intercultural mediation is essentially also intercultural communication, which can be facilitated through several strategies, namely by using effective communication strategies, adequate resources and learning/teaching approaches that will render communication among culturally different people easier. A couple of examples of the latter are creative uses of resources and comparisons or contrasts of information and resources. Additionally, experiential practices about other cultures, peoples and places can be introduced into classrooms from very early on, so that exchanges of information and knowledge with other children become routine. Digital resources are key to these exchanges, such as the e-twinning platform or setting up telecollaborative individual, group or class projects (virtual online exchanges) and even study visits abroad.

\section{REPRESENTING SUPERDIVERSITY}

A little bit of context may be required to identify arguments prior to intercultural mediation through picturebooks to address the topic of "Imagining the global world and hoe children build linguistic identities".

The emergent world community (Israel, 2012, p. 79) due to global mass migration, characterised by global mobility of people and the decline of homogeneous communities gives rise to new educational contexts that need to explore exchanges, peer relations, collaboration and cooperation, interdisciplinary work and new roles for languages and other 
school subjects, but above all has to focus on the new skills and competences needed to survive in the world.

The inherent problems are linked to emergent social and demographic patterns of many European countries. There are pressures on the concepts social workers and the public in general hold on migrants and multicultural societies. There are new complexities of how the new migrants or foreigners occupy territories, in small dispersed groups, from multiple origins, with some transnational connections, economically and socially differentiated, with diverse political and legal statuses, (seasonal workers, tourists, special visa holders, managerial staff in multinational companies, refugees, migrants, foreign exchange students, asylum seekers, etc.).

The emergent problems are often of a cultural and linguistic nature (users of diverse language-cultures using the same territory and the need to communicate in the framework of cultural diversity) and they express the superdiversity described by Vertovek (2006), a concept which reflects the diverse social, national, ethnic, and linguistic variables that intersect and influence the trajectories, social milieus and highly differentiated composition of migrant groups in the $21^{\text {st }}$ century. In London alone, according to the author, who cites Baker and Mohieldeen (2000), and just to quote an example, 300 languages are spoken in schools (a number based in a total number of school pupils of 896.743), which puts schools, local councils and other public services under tremendous stress. Moreover, linguistic superdiversity is also accompanied by growing religious diversity within, for example, the Muslim group, based on origin, and transnational migrant cultural practices are today more varied than they ever were in the past (Vertovek, 2006). There is, thus, the additional risk of groups living parallel lives without significant intercultural relationships in the same territory (Vertovek, 2006, p. 27).

Thus, we conclude that for understanding contemporary social realities, it is important to contact with representations of mixed neighbourhoods, where people meet each other in their daily routines (commuting, shopping, going to school, etc.). This is a valuable idea to show how ethnic, social, gender, age, and location variables intersect in the context of daily life.

\section{REPRESENTING LINGUISTIC DIVERSITY}

One of the strategies used to cope with superdiversity is the preservation and promotion of multilingual policies (learning or valuing the use of several languages throughout life). This should be accompanied by strategies of social cohesion and inclusion, such as accepting, valuing and interacting with people that are different from us.

However, the use of a lingua franca for communication, such as English, is a strategy put into place to guarantee some linguistic unity. Thus, English is one of the foreign languages most widely learned at primary schools.

The hegemony of English in the world may be looked upon as a power structure of domination, but English may also be looked at as a language connected to a myriad of linguistic identities, used to mediate between mother tongues (as a foreign or second language) (Breidbach, 2003). 
Since the most relevant political, economic, social, cultural, ecologic and technological issues that affect peoples' lives are decided globally and cannot be contained either geographically or socially, participation at the local, national and supranational levels presuppose a heightened linguistic awareness about which language to use and how to interact with speakers of other languages on equal terms and through valuing their own and others' multiple linguistic identities.

A plural, diverse and intercultural society cares about how ideas, opinions and perspectives on reality are shared, no matter how diverse they reveal themselves to be. Multilingual education that is intercultural is happy to accommodate the needs of a diverse community. It accepts and integrates multiple new experiences that arise from the circumstances and the needs of diverse groups, cultures and identities. These may fall within the private realm of family, friends, daily chores, and forms of address, as within the public realm, such as for example being a student in a school.

Consequently, picturebooks should render diverse linguistic identities visible, not only as a means to present a multilingual worldview, but also in order to promote multiple cultural competence, inter-language (Rampton, 2005) and multilingual practices (Harris, 2003).

\section{SEVERAL STORIES ON THE SAME TOPIC: MIGRATING}

In their concrete lives, children are offered diverse images and stories of migrants, refugees, relatives that have moved to another country or have come back, as well as the many reasons that have led them to do so. These may be unique stories that simplify complex situations and malign some characters or situations. They may also be isolated images that are difficult to understand, as children lack contextual information.

In order to render justice to contemporary social complexity, human mobility must be framed as a cultural encounter that may be either negative (causing fear, anxiety and violence) or positive (in the sense of an opportunity for innovation and creativity). A cultural encounter may result both in cultural shock, as in group and cultural intersections that give rise to new social arrangements. It may cause segregation, conflict and war, as it may give rise to new creative and innovative ways of life.

When looked at in this way, the concept of human mobility opens up space to understand how individual and group identities are in constant flux, intersecting spaces, (historical) time and imagination.

Thus, it is important to explore intercultural encounters in several stories, with examples of continuities and discontinuities that occur in the mobility situations told by picturebooks, while simultaneously making clear that picturebooks are cultural practices of adults for children and ways of telling and showing, even imagining, society that can be discussed. As such picturebooks will become key contributors to political and ideological education and communicate certain ideas and meanings (Lewis, 2002). 


\section{SELECTED PICTUREBOOKS}

The use of images and pictures as storyboards, as is the case in picturebooks and graphic novels, has often been utilised in European contexts as a strategy to familiarise migrant children and children from various minority ethnic backgrounds with multiple representations of the societies they inhabit and with the social capital of school. A recent example with wide media coverage is the creation of a library of picturebooks with no words for the Lampedusa island refugee children called Silent books: final destination Lampedusa?.

Is there a more expressive language for a child than a succession of pictures to create a story (with or without words), which engages the child's imagination in construing and re-construing her own experience, while attempting to interpret what she sees from her own implicit or explicit resources of cultural knowledge while using her own linguistic repertoires?

Visual images are dominant in the first years of structured learning and are used to explore children's emotions and worldviews. Children's literacies are intricately woven with the ways in which children learn to see and are able to recognise what they see (Meek, 1991). As much as they need to learn to read, children need to learn how to look at pictures in a picturebook, since they will never be able to do so, if they are not explicitly taught or shown how to do it. Pictures in a picturebook are not just illustrations of the printed words; they are a distinct form of representation that uses specific semiotic codes shared not only by literature, but also by television, film, audio-visual and digital production.

Additionally, as pointed out by Meek (1991), by perusing picturebooks, we are making several assumptions, namely that we live in a culture where pictures and narratives that use pictures matter and are common ways to organize the world; but also that books for children are also used by other audiences and that picturebooks are at the heart of debates about how to transition from a print-based literacy to multiliteracies, how to teach visual literacy and transcultural narrative conventions (discourse varieties, multiple ways of learning, presenting and representing reality, diverse articulations of world issues).

Finally, by creating conditions for the child to interact culturally with the pictures in a picturebook, we are creating the space for learning practices of mutual acceptance and integration of the cultural capital represented in the picturebooks and the child's own cultural capital. These practices lie at the heart of the prevention of segregation, isolation, and closure of those who do not see themselves or their experiences (or languages) represented in media perused at school.

\section{IDENTITY AND DIVERSITY IN PICTUREBOOKS: THE IDPBC COLLECTION}

The pedagogical approach presented uses as resource an international collection of picturebooks called Identity and Diversity in Picture Book Collections. The IDPBC project developed an annotated catalogue of 24 picturebooks for children aged five to 12 years on

\footnotetext{
Available at http://www.ibby.org/awards-activities/activities/silent-books/
} 
the themes of identity and diversity. This catalogue is available online, as a flip book ${ }^{2}$. The catalogue summarily describes a collection of international contemporary picturebooks, partly available online, that have the educational potential to develop all competences described above. The aim of the collection and of the didactic suggestions that accompany them is to equip educators, teachers and social workers with resources and competences to mediate new social realities with children and young people through informal (familial, social and ethnic networks), non-formal and formal educational activities.

By contrast to other fictional resources, picturebooks afford diverse benefits to diverse groups of learners and in particular to reluctant pre-readers (Botelho \& Rudman, 2010; Cotton \& Daly, 2014; Roche, 2010, 2015) or children who speak other languages than the official languages of school. Visual representations are easier than printed text to yield to polyphonic interpretation based on each reader's own experience.

Graham (1990, p. 27) points out that a child reads pictures in a picturebook as real life behaviour, thus gaining information on how people from different cultures live and interact and intrinsically absorbs diverse forms of cultural interaction. Baghban (2007, p. 71) recognises in picturebooks the potential to help migrant children deal with the challenges they are facing, such as, for example, relating with older generations and their traditions, keeping in contact with relatives that live far away, and weaving positive bonds with the homeland. This may be of particular relevance in a globalised technological world of massive voluntary and enforced mobility.

We will proceed now to identify the picturebooks from the collection that could be used to comply with the intercultural mediation objectives set above: To represent multicultural and multi-ethnic neighbourhoods, where people meet each other in their daily routines (commuting, shopping, schools), Last stop on market street (de la Pena \& Robinson, 2015) and We are all born free (Amnesty International, 2015) were selected. My two blankets (Kobald \& Blackwood, 2014) was chosen to represent diverse linguistic identities and multilingual practices. Finally, in order to explore intercultural encounters in several stories, with examples of continuities and discontinuities that occur in the mobility situations, four picturebooks were selected, namely Migrando (Mateos, 2010), Azzi in between (Garland, 2012), Akim court (Dubois, 2012) and The Island (Greder, 2008).

The next section briefly introduces each picturebook and some suggestions on how it can be used with children in the framework described above.

\section{INTERCULTURAL DYNAMICS}

It is known that access to resources is simply not enough to support educators in promoting $21^{\text {st }}$ century educational goals. Thus, it is important to present picturebooks in connection with some inclusive transversal strategies of how to use them for the purposes described above. Inclusive activities with picturebooks could include relating the

${ }^{2}$ Available at http://www.diversitytales.com/flipbooks/bookcollection/

Annotated bibliographic catalogue. Available at http://diversitytales.com/flipbooks/bookcollection/files/assets/basic-html/ page-1.html

Guide for enhancing inclusive practices. Disponível em http://diversitytales.com/resources/IDPBC_Guide.pdf 
visual text with the child's own personal experience; help the child find her own voice to give an opinion on what she sees; invite the child to use several languages (verbal, visual, kinaesthetic) in order to express her own meanings; invite children to react actively to what they are looking at; or explore themes, topics and ideas that emerge from the picturebook by inviting diverse and multiple perspectives.

If the aim is to help develop in children global citizenship and intercultural communicative competence, there is something worth remembering, which is that children think in images first and only after that, in words. Images and pictures are a language that approximates the child to the story, especially so if they do not feel at ease with the language of the host country.

Additionally, there must be prompts to explore pictures, so open questions should be asked in order to activate how children read pictures. A couple of examples are given for each picturebook.

\section{COSMOPOLITAN LIVING WITH OTHERS}

Last stop on market street (de la Pena \& Robinson, 2015) and We are all born free (Amnesty International, 2015) represent mixed neighbourhoods where people meet each other in their daily routines (commuting, shopping, or going to school).

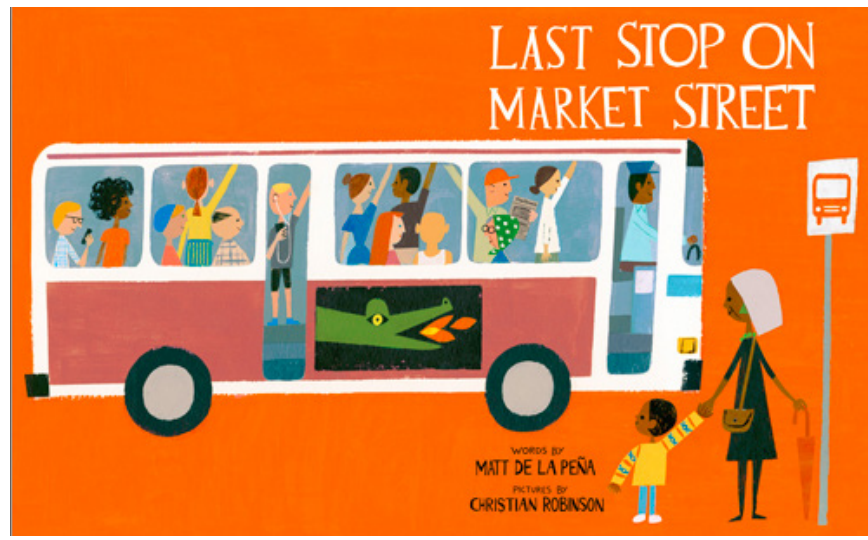

Figure 1: Cover of Last stop on Market Street

Source: de la Pena and Robinson, 2015

Last stop on Market Street (2015), by Matt de la Pena and Christian Robinson, tells the story of an Afro-American boy who catches a bus with his grandmother. On the way to their destination, which is kept secret till the very end of the picturebook, the boy, C), keeps asking questions about why he does not own a car like his friend Colby; or why he doesn't have an IPod like the other boys that are riding the bus, etc.; and to each of his questions, dictated by comparison with others, envy or jealousy, CJ's grandmother Nana answers lightly, by making him value what he has rather than what he doesn't, especially the people that surround him. On the bus grandmother and grandson strike a conversation with a blind man, listen to a guitar concert and eventually, while they follow after a 
man in a wheelchair, they arrive at a community kitchen where CJ's grandmother and CJ himself help out on a voluntary basis.

Suggestions to explore the picturebook: What is 'inner beauty'? Look around you and identify all that you do not think as beautiful. Draw those things on paper.

Or: Do you know where to go and who to address if you wanted to do voluntary work like $\mathrm{C}$ ) and Nana? You could do it among your relatives...

Or: How can diversity make your community stronger? Create a book on the diversity of your community.

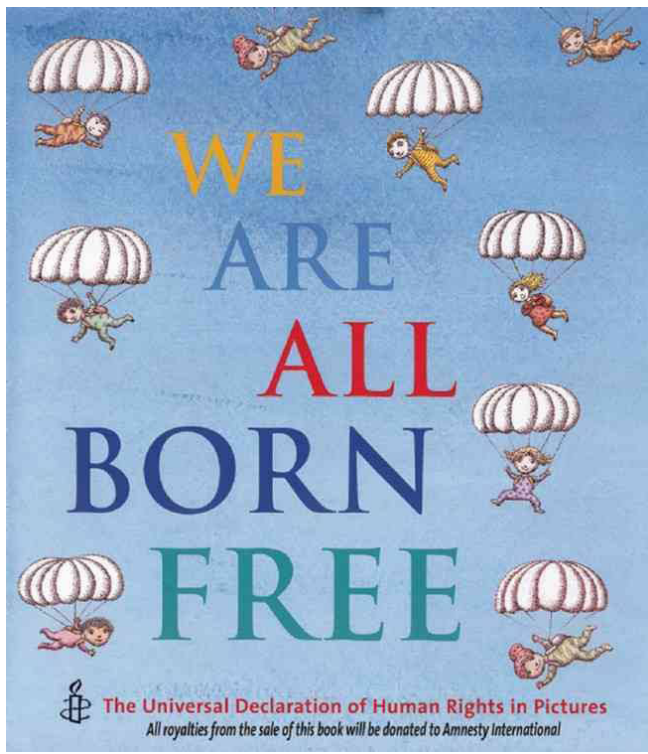

Figure 2: Cover of We are all born free

Source: Amnesty International (2015)

We Are All Born Free, by Amnesty International (2015), is a version of the Human Rights Declaration by 30 of the top illustrators in the world. In a variety of styles of illustration, the picturebook explores human life across diverse contexts and situations, while promoting concrete real contexts for each Human Right with children at the heart of each visual scene. The pictures in themselves are already debate cues to explore reasons why people come from diverse origins, what characteristics they share with one another, similarities and differences, and how to respect those that are different from us.

Suggestions to explore the picturebook: Create stories from each page; Draw the Human Rights; Role play the characters represented in each picture and create drama scenarios with dialogue. 


\section{AsSUMing MULTILINGUAL IDENTITIES}

The picturebook by Irena Kobald, illustrated by Freya Blackwood, My two blankets (2014), was selected to explore how children build linguistic identities, how they learn a new language and by learning it, change their outlook on life.

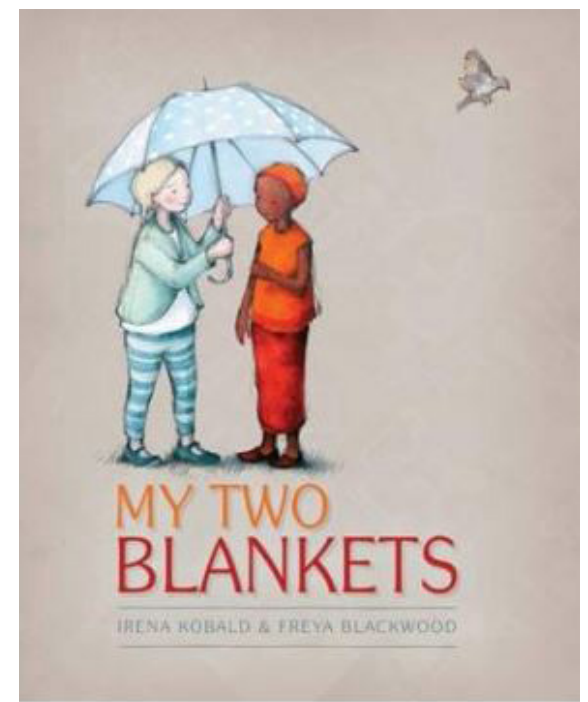

Figure 3: Cover of My Two Blankets

Source: Kobald and Balckwood, 2014

My two blankets (Kobald \& Blackwood, 2014) tells the story of a recently arrived girl from a culture that can be presumed as African, given the colours used (orange, red) and the straw hut like houses. Allegedly she has moved away from her homeland for security reasons and is now living in a probably European-like city, represented through pale blues, greys and beiges. There she feels odd. Everything looks strange: food, animals, plants, and wind. There is a stream of odd words around her, so strong that she feels annihilated. That is why she takes refuge in her old blanket, covered in objects that she feels safe with. In her blanket she feels safe, so safe she does not feel the need to interact with what goes on around her. While walking in the park with her mother, for the third time, she meets a local girl she has seen before. She does not know her language, but she recognises the smile. A friendship grows, which does not, however, erase her solitude and sadness, until the girl starts bringing her new words, more and more words. These words start decorating the girl's new blanket and to lose their cold and harsh characteristics. The new blanket is, at first, small and thin, until it grows into something as comfortable, mild and warm as the precious first blanket and until she wears both blankets comfortably.

Suggestions to explore the picturebook: How would you feel if you had to remain in another country for a long period of time? Look at the end papers of the picturebook and select the objects you consider most important. Which would you carry with you if you could only take 10? 
Or: What is a blanket? What is it for? How do you feel in relation to a blanket? Does everybody feel the same way?

Or: Compare the blanket the main character feels comfortable with and that she covers herself with to sleep with the new blanket she creates: do they have the same shape? Do they have the same colours? Do they represent similar objects?

Or: Draw a blanket for your mother tongue: think of shape, colour and objects you would decorate it with. Next, draw another blanket for another language you know: think again about shape, colour and objects you would decorate it with. Compare your blankets with those of your colleagues. What would you add or remove from your blankets?

\section{PerspeCtives on Migration AND MOBility}

Is it relevant to debate with children human rights and the rights of migrants, refugees or asylum seekers? In our opinion, it is, because children are surrounded by these issues, they have heard them in the news and adults talking, and also because they have probably already experienced situations of injustice, prejudice, conflict, of deciding against the flow of the majority or condoning with majority decisions.

The following four picturebooks present and represent diverse perspectives on types of contemporary human mobility: voluntary and enforced, when people search for work or for better living conditions elsewhere, when they flee armed conflicts, from the perspective of those who arrive in a new territory and of those who flee a territory, with happy and not so happy endings, or even unfortunate endings, through several different visual styles, by authors from diverse language cultures, using a wide range of colours or just primary colours, black and white, in comics style, pencil drawing, etc.

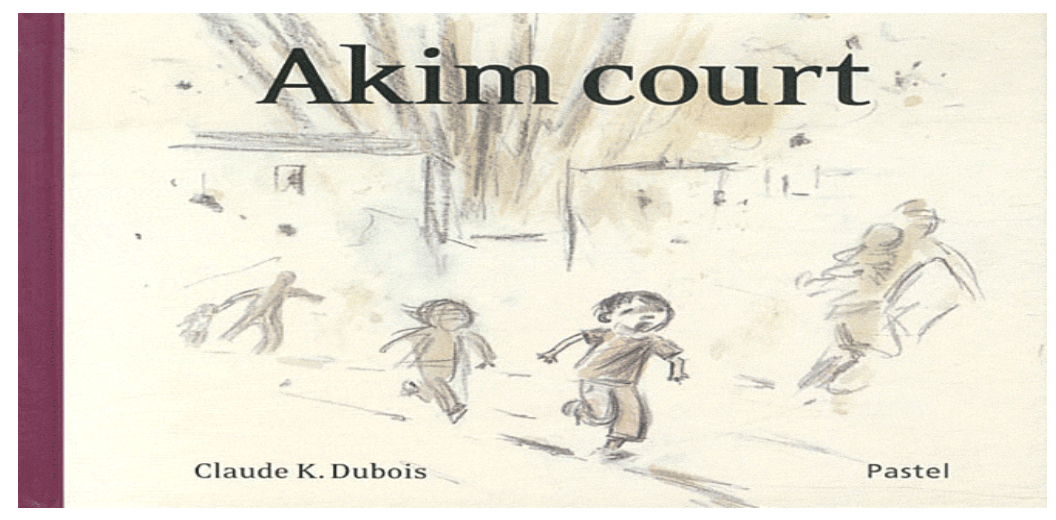

Figure 4: Cover of Akim court Source: Dubois, 2012 
Akim court, by C.K. Dubois (2012), tells the story of a boy child who runs away from armed conflict, is caught by soldiers and eventually arrives at a refugee camp. Akim is the child lost in a war zone. At the beginning, Akim is just a child playing football with other children outside home. Then he experiences violence, loss, alienation and lives the drama of becoming a refugee. Throughout the story Akim holds on to a bond with his mother by looking for and hanging on for protection to other fleeing women with children. This story is predominantly visual, in pencil drawings, interspersed with some printed text that sums up several drawings in sequence.

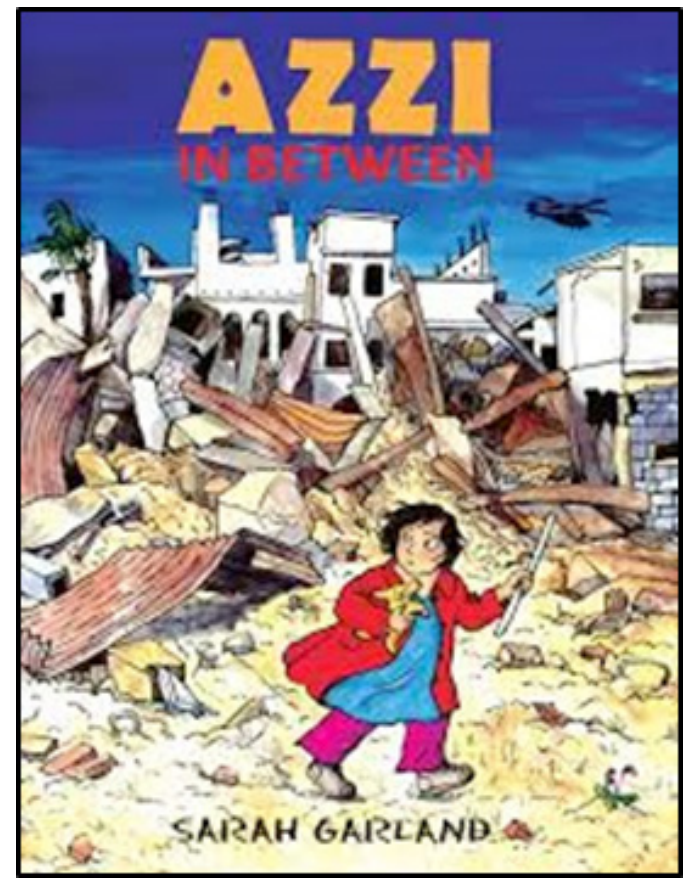

Figure 5: Cover of Azzi in between

Source: Garland, 2012

Azzi in between, by Sarah Garland (2012), tells the story of how a migrant family (father, mother and child) tries to adapt to the new culture after a dreadful car and boat journey. Adapting to the new culture implies learning a new language, finding a home and going back to school. Azzi learns the new language, makes a new friend, shares her story with children who have similar stories and simultaneously keeps holding on to her own home culture. She has brought with her a seed that eventually germinates in the new home. This story encourages readers to respond emotionally to fear, separation, loss, hope and the ability to start a new. 


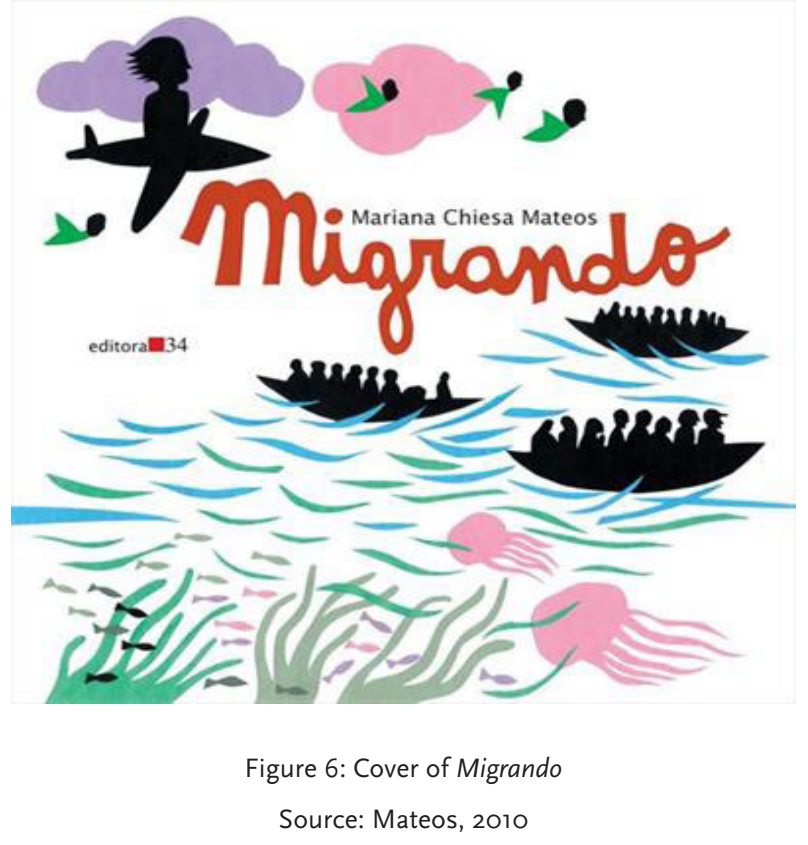

Migrando, by Mariana Chiesa Mateos (2010), is a wordless picturebook (apart from title), which tells a story of emigration up to the middle of the book and then requires the reader to turn the book around and read it from the back cover to the middle, where a story of immigration is depicted. It connects human migration to other animal migrations, such as those of birds, which exhibit little human heads, and covers a wide range of means of transportation (train, plane, boat), while focussing on emotions connected both to leaving and arriving.

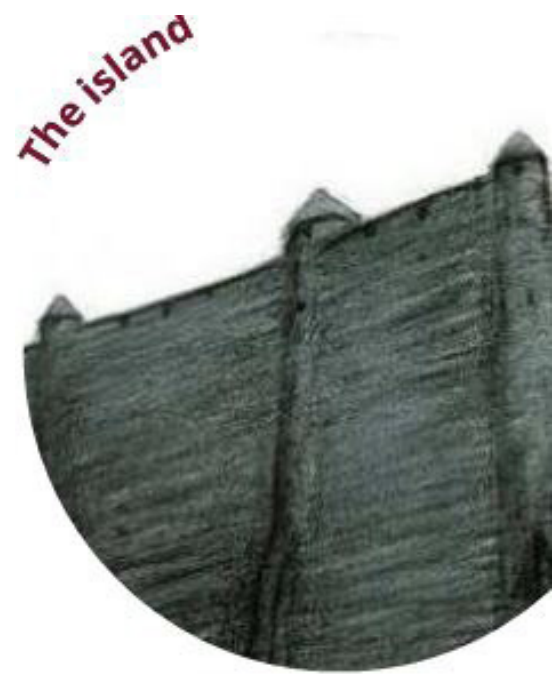

Figure 7: Cover of The island

Source: Greder, 2008

The island, by Armin Greder (2008), is a dark picturebook (some might qualify it as a graphic novel) about a community which refuses to integrate a castaway or to 
allow him to settle on their fortress-like island. In the end the castaway is driven back to the sea, off a cliff and left to die. Important moral principles and relative values are dramatized through the narrative. Readers are made to reflect on the meaning of social justice, accepting the strangeness of others, becoming a host country. The graphic novel also approaches issues of exclusion, linguistic and cultural barriers, xenophobia, lack of knowledge about the others, fear and prejudice. It further exhibits the emotions of those that look for protection, such as sadness, isolation, absence of human relationships, courage and despair.

Suggestions to explore the picturebook: Show the covers of the four picturebooks and invite readers to think themselves as the main character of one of those stories. Which would you like to be? Why? What would you feel? How do you know those would be your emotions?

Or: By juxtaposing several pictures from the four picturebooks one could ask a series of questions: how would you treat a migrant or a refugee? Have you ever travelled? Was everything the same? What was different? What did you feel? Which do you think would be the new experiences of a refugee or migrant in your country? (This activity would work best if the social worker or educator selected 4 pictures that are related to routines, such as going to school, fear, touching another human being or doing house chores such as cleaning, cooking or eating).

Or: New sequence of pictures from several picturebooks about getting together followed by questions such as: What does it mean to be entitled to a home? How do you feel at home? What do you do at home? Who is at home? How would you welcome Azzi in your home? How would you make Azzi feel at ease?

Or: Use a sequence of pictures from the above picturebooks: a fortress, a girl reading, boys playing football outside, a school where children are engaged in learning. Ask the following questions: what makes a place safe? Why do we fear other people? Is fear something you build up or is it something inherent to things, animals, and people? Why do we fear the unknown? What is courage? How would you rewrite these stories?

\section{Conclusions}

To reflect on contemporary social conditions with children requires adequate resources, such as a collection of picturebooks able to communicate unstable meanings and imagination (Lewis, 2002), to be explored by prospective readers. Meanings and imagination as conveyed in these resources should invite meaning making so that readers 
are led to build, negotiate and transform their worldviews (Botelho \& Rudman, 2009).

It is also to be expected that there will be disjunctions between the interpretations offered by adults on picturebooks and responses given by children and young adults. Both groups will hold different interests, share different circumstances and probably have quite different notions on what reading means.

It has been attempted to show what may be achieved from a pedagogical point of view. First, to compile a collection of picturebooks that may be representative of an approach and has the ability to reproduce and distribute meanings. Next, to present suggestions on how to explore these books with readers so as to generate opportunities for them to learn about the world and develop the necessary competences to act in it.

The contemporary social world being what it is, picturebooks were emphasised for their potential to promote the visual literacy of children.

However, it must be also clear what was not done. Picturebooks about specific ethnic groups or about particular cultures were neither presented nor promoted. Even when the topic of refugees was explored, the topic was placed within the framework of migration that is variously motivated and from the perspective of several literary and cultural traditions through the use of picturebooks from diverse linguistic cultures.

\section{FUNDING AND ACKNOWLEDGEMENT}

Part of this publication uses resources developed for the "IDPBC - Identity and Diversity in Picture Book Collections" project, funded by the Erasmus+ programme under the contract number 2015-1-LTO1-KA201-013492. The author herself was content developer for this project.

Disclaimer: This text reflects the views only of the author herself, and the Education, Audiovisual and Culture Executive Agency and the European Commission cannot be held responsible for any use which may be made of the information contained therein.

Translation: Margarida Morgado

\section{REFERENCES}

Adichie, C. N. (2009). The danger of a single story. [Vídeo]. Retrieved from https://www.ted.com/talks/ chimamanda_adichie_the_danger_of_a_single_story?language

Amnesty International (2015). We are all born free. London: Frances Lincoln Children's Books.

Baghban, M. (2007). Immigration in childhood: using picture books to cope. Social Studies, 98(2), 71-76. https://doi.org/10.3200/TSSS.98.2.71-76

Baker, P. \& Mohieldeen, Y. (2000). The languages of London's schoolchildren. In P. Baker \& J. Eversley (Eds.), Multilingual capital (pp. 5-60). London: Battlebridge.

Botelho, M. \& Rudman, M. K. (Eds.) (2010). Critical Multicultural analysis of children's literature. Mirrors, windows, and doors. New York: Routledge. 
Breidbach, S. (2013). Plurilingualism, democratic citizenship in Europe and the role of English. Strasbourg: Council of Europe.

Bruner, J. (1986). Actual minds, possible worlds. Cambridge, M. A.: Harvard University Press.

Byram, M. (1997). Teaching and Assessing intercultural communicative competence. Clevedon: Multilingual Matters.

Cotton, P. \& Daly, D. (2014). Visualising cultures: the "European picture book collection" moves "down under". Children's Literature in Education, 46(1), 88-106. http://doi.org/10.1007/s10583-014-9228-9

de la Pena, M. \& Robinson, C. (2015). Last stop on market street. New York: G.P. Putnam's Sons Books for Young Readers.

Djikic, M., Oatley, K. \& Moldoveanu, M. C. (2013). Reading other minds. Effects of literature on empathy. Scientific Study of Literature, 3(1), 28-47. https://doi.org/10.1075/ssol.3.1.06dji

Dubois, C. K. (2012). Akim court. Paris: L'école des loisirs.

Garland, S. (2012). Azzi in Between. London: Frances Lincoln Children's Books.

Graham, J. (1990). Pictures on the page. Sheffield: National Association for Teaching English.

Greder, A. (2008). The island. Sydney: Allen \& Unwin.

Gregersen-Hermans, J. (2015). The impact of exposure to diversity in the international university environment and the development of intercultural competence in students. In A. Curaj, L. Matei, R. Pricopie, J. Salmi \& P. Scott (Eds.), The European higher education area (pp 73-92). Cham: Springer. https://doi. org/10.1007/978-3-319-20877-0_6

Harris, R. (2003). Language and new ethnicities: multilingual youth and diaspora. London: King's College Working Papers in Urban Language \& Literacies.

Israel, R. C. (2012). What does it mean to be a global citizen? Kosmos, 79. Retrieved from http://www. kosmosjournal.org/wp-content/article-pdfs/what-does-it-mean-to-be-a-global-citizen.pdf

Kobald, I. \& Blackwood, F. (2014). My two blankets. Australia: Little Haire Book.

Lewis, J. (2002). From culturalism to transculturalism. lowa Journal of Cultural Studies, 1, 14-32. https://doi. org/10.17077/2168-569X.1003

Mateos, M. C. (2010). Migrando. Lisboa: Orfeu Negro.

Meek, M. (1991). On being literate. London: Random House Children's Publishers.

Mendenhall, M. E., Stevens, M. J., Bird, A., Oddon, G. R. \& Osland, J. S. (2001). Intercultural effectiveness scale. Technical report. Chesterfield: The Kozai group, Inc.

Ministério da Educação. (n.d.). Organização curricular e programas. Estudo do Meio (pp. 100-114). Lisboa: Ministry of Education. Retrieved from https://www.dge.mec.pt/sites/default/files/Basico/Metas/ Estudo_Meio/eb_em_programa_1c.pdf

Oxley, L. \& Morris, P. (2013). Global citizenship: a typology for distinguishing its multiple conceptions. British Journal of Educational Studies, 61(3), 301-325. https://doi.org/10.1080/00071005.2013.79839

Parekh, B. (2013). Cosmopolitanism and global citizenship. Review of International Studies, 29, 3-17. https:// doi.org/10.1017/So260210503000019 
Portalla, T. \& Chen, G.-M. (2010). The development and validation of the intercultural effectiveness scale. Intercultural Communication Studies, XIX (3), 21-37. Retrieved from https://web.uri.edu/iaics/ files/O2TamraPortallaGuo-MingChen.pdf

Rampton, B. (2005). Crossing: language Q ethnicity among adolescents. Manchester: St Jerome Press.

Roche, M. (2010). Critical thinking and book talk: using picture books to promote discussion and critical thinking in the classroom. Reading news (Conference edition). Dublin: Reading Association of Ireland.

Roche, M. (2015). Developing children's critical thinking through picture books. A guide for primary and early years' students and teachers. Oxon: Routledge.

Sen, A. (2006). Identity and violence: the illusion of destiny. London: W.B. Norton and Co. Ltd.

Speer, N. K., Reynolds, J. R. \& Zacks, J. M. (2009). Reading stories activates neural representations of visual and motor experience. Psychological Science, 20(8), 989-999. https://doi. org/10.1111/j.1467-9280.2009.02397.x

Unesco. (n.d.). Media and information literacy. [Web portal]. Retrieved from http://www.unesco.org/new/en/ communication-and-information/media-development/media-literacy/mil-as-composite-concept/

Vertovec, S. (2006). The emergence of super-diversity in Britain. Compass, Working Paper No 25. Oxford: University of Oxford.

\section{BIOGRAPHICAL NOTE}

Margarida Morgado is Coordinating Professor of English Cultural Studies at the Higher School of Education, Polytechnic Institute of Castelo Branco, Portugal, where she teaches. Her research is on teaching English, intercultural education, communication and mediation, as well as reading and children's fiction.

ORCID: https://orcid.org/o0oo-0002-3651-3030

Email: marg.morgado@ipcb.pt

Address: Escola Superior de Educação, Rua Professor Doutor Faria de Vasconcelos 60oo-266 Castelo Branco

* Submitted: $20 / 07 / 2018$

* Accepted: 21/09/2018 